\title{
A Study on the Road Conditions Assessment Obtained from International Roughness Index (IRI): Roughometer Vs Hawkeye
}

\author{
Saleh Samsuri, Medis Surbakti, Ahmad Perwira Tarigan, Ridwan Anas \\ Civil Engineering Department, Faculty of Engineering, Universitas Sumatera Utara, Medan 20155
}

\begin{abstract}
IRI (International Roughness Index) from the Roughometer results if it was used as substitute of IRI from the Hawkeye results on the road conditions assessment, which is the hawkeye device is included in the Class I category of roughness measurement devices, while the Roughometer is in the Class III. The Student's t statistical operation is used to find the representation of IRI from the Roughometer results as substitute of IRI from the Hawkeye results. It is determined by analyzing the comparison of the mean values of both measurement results. The study was conducted on three national road sections in North Sumatra Province, namely: Bts. Kota Binjai - Bts. Kota Medan road with a length of 7,300 meters, Bts. Kota Tebing Tinggi - Bts. Kabupaten Simalungun road with a length of 18,800 meters, and Bts. Kabupaten Simalungun/Bts. Kabupaten Sergai road with a length of 15,000 meters. The IRI values were measured by using Roughometer and Hawkeye devices. The measurements were carried out with the survey team from the Center for Implementation of the National Road II Medan, which was also the facilitators in providing the survey equipment, Roughometer and Hawkeye. The statistical test results that the IRI values from the Roughometer measurement results were significantly different from the IRI values from the Hawkeye measurement results (Ho was rejected) because the Student's t-test results for the three road sections showed that $t_{\text {count }}>t_{\text {critical }}$ and $\mathrm{p}$-value $<0.05$. And the assessment of the road functional conditions using Roughometer showed the same results on one road section but worse results on the other two road sections compared to assessment of the functional conditions with Hawkeye. Based on the analysis results, it can be concluded that the IRI values from Roughometer were more conservative in representing the functional conditions of the road when used as a substitute for the IRI values from Hawkeye.
\end{abstract}

Keywords: International Roughness Index, Road Conditions Assessment, IRI Representation

\begin{abstract}
Abstrak. Penelitian ini bertujuan untuk mengetahui representasi IRI (International Roughness Index) dari hasil Roughometer jika digunakan sebagai pengganti IRI dari hasil Hawkeye pada penilaian kondisi jalan, yang mana perangkat hawkeye termasuk dalam Kelas I kategori perangkat pengukuran kekasaran, sedangkan Roughometer berada di Kelas III. Operasi statistik Student digunakan untuk menemukan representasi IRI dari hasil Roughometer sebagai pengganti IRI dari hasil Hawkeye. Ini ditentukan dengan menganalisis perbandingan nilai rata-rata dari kedua hasil pengukuran. Penelitian dilakukan pada tiga ruas jalan nasional di Provinsi Sumatera Utara, yaitu: Bts. Kota Binjai - Bts. Jalan Kota Medan dengan panjang 7.300 meter, Bts. Kota Tebing
\end{abstract}

\footnotetext{
*Corresponding author at: Civil Engineering Department, Faculty of Engineering, Universitas Sumatera Utara, Jl. Almamater, Medan 20155

E-mail address: salehharahap12@gmail.com
}

Copyright ( 2019 Published by Talenta Publisher, p-ISSN: 2656-1476, e-ISSN: 2655-8599

Journal Homepage: https://talenta.usu.ac.id/index.php/jet 
Tinggi - Bts. Jalan Kabupaten Simalungun dengan panjang 18.800 meter, dan Bts. Kabupaten Simalungun / Bts. Jalan Kabupaten Sergai dengan panjang 15.000 meter. Nilai IRI diukur dengan menggunakan perangkat Roughometer dan Hawkeye. Pengukuran dilakukan dengan tim survei dari Pusat Implementasi Jalan Nasional II Medan, yang juga merupakan fasilitator dalam menyediakan peralatan survei, Roughometer dan Hawkeye. Hasil uji statistik bahwa nilai-nilai IRI dari hasil pengukuran Roughometer berbeda secara signifikan dari nilai-nilai IRI dari hasil pengukuran Hawkeye (Ho ditolak) karena hasil uji-t Student untuk tiga bagian jalan menunjukkan bahwa thitung> tcritical dan p-nilai <0,05. Dan penilaian kondisi fungsional jalan menggunakan Roughometer menunjukkan hasil yang sama pada satu ruas jalan tetapi hasil yang lebih buruk pada dua ruas jalan lainnya dibandingkan dengan penilaian kondisi fungsional dengan Hawkeye. Berdasarkan hasil analisis, dapat disimpulkan bahwa nilai IRI dari Roughometer lebih konservatif dalam merepresentasikan kondisi fungsional jalan ketika digunakan sebagai pengganti nilai IRI dari Hawkeye.

Kata kunci: Indeks Kekasaran Internasional, Penilaian Kondisi Jalan, Representasi IRI

Received 08 March 2019 | Revised 09 May 2019| Accepted 27 September 2019

\section{Introduction}

Assessment of the right conditions by using developing methods or technology will have an impact on the effectiveness and efficiency of the determination of maintenance types of a road section [1]. Improper type of maintenance will result in a waste of money and failure to achieve road service functions until the planned time. Studies, therefore, should be conducted on the supporting methods and instruments to assess the existing and currently developing road conditions, especially in Indonesia. Hawkeye is a survey device for Class I functional conditions [2], whose number is limited in Indonesia. Unlike Hawkeye, Roughometer is more commonly used for functional road surveys in Indonesia. Related to this, the present study examined the representation of the International Roughness Index (IRI) from the Roughometer results if it was used as the substitute of the International Roughness Index (IRI) from the Hawkeye results in the assessment of national road conditions in North Sumatra[3]. The research was conducted on three national roads, namely:

1. The road section of Bts. Tebing Tinggi-Bts. Simalungun (063): 18,800 meters

2. The road section of Bts. Simalungun-Bts. Pematang Siantar (064): 15,500 meters

3. The road section of Medan-Binjai (006): 7,300 meters

The pavement type of the three road sections studied was flexible pavement. The survey device used to determine IRI was Roughometer III and Hawkeye 2000. The representation of the use of IRI from the Roughometer results if it was used as a substitute of IRI from the Hawkeye results was determined based on the statistical hypothesis testing[4]. The hypothesis for the statistical test performed was: "It was assumed that there was no statistically significant difference in the 
measurement of the IRI mean values using Roughometer and Hawkeye devices in terms of assessing the road functional conditions" [5].

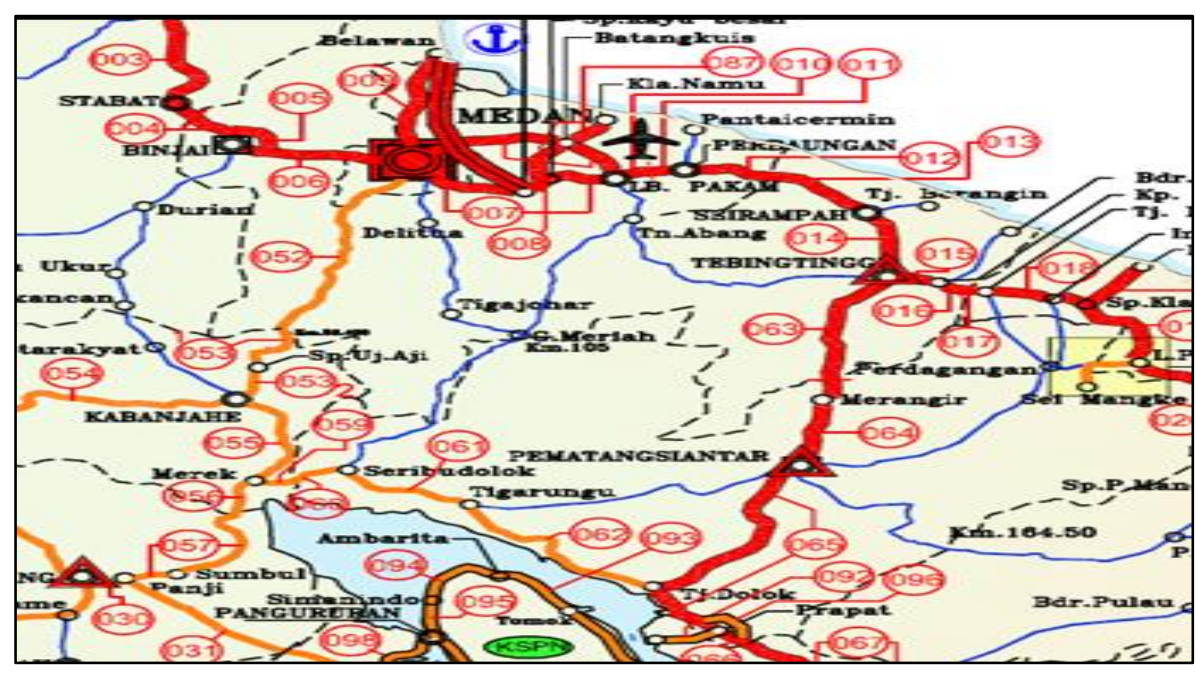

Figure 1. National Road Network of North Sumatera

\section{Literature Review}

\subsection{International Roughness Index (IRI)}

IRI is one of the parameters in the method of determining the functional conditions of road pavement recommended by the Directorate General of Highways and AASHTO[6]. The International Roughness Index (IRI) is defined as: "The deviations of a pavement surface from a true planar surface with characteristic dimensions that affect vehicle dynamics, ride quality, dynamic loads, and drainage; for example, longitudinal profile, transverse profile and crossslope" [7]. The IRI value is expressed in meters per kilometer of the road length $(\mathrm{m} / \mathrm{km})$. As one of the technical indicators to assess the performance of road surface; if it is quite flat, the road is good from the bottom to the top layer of the road pavement, and vice versa [7]. The IRI scale describes the condition of the road surface as shown in Figure 2. Below.

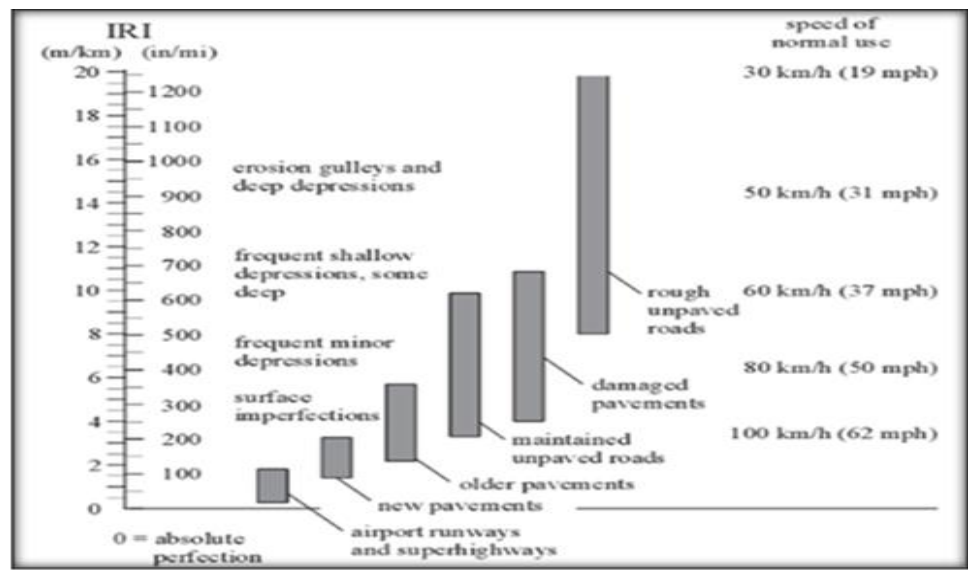

Figure 2. International Roughness Index Scale [7] 
If the IRI value given is greater, the surface condition of the pavement will be worse. The Directorate General of Highways, the Ministry of Public Works and Housing[8], describes IRI values with the surface conditions of a paved road as shown in Table 1.

Table 1. Criteria of Road Conditions Based on the IRI Values in Paved Surface Type

\begin{tabular}{cc}
\hline IRI Value & Category of Road Conditions \\
\hline IRI $\leq 4$ & Good \\
$4<\mathrm{IRI} \leq 8$ & Fair \\
$8<\mathrm{IRI} \leq 12$ & Slightly Damage \\
IRI $>12$ & Heavily Damaged \\
\hline Source: Directorate General of Highways [8]
\end{tabular}

In the assessment of the road functional conditions, the ASTM E 950-94 standard classifies equipment used to measure roughness into four classes [6] as shown in Table 2.

Table 2. Examples of Equipment to Measure Roughness

\begin{tabular}{ll}
\hline \multicolumn{1}{c}{ Class } & \multicolumn{1}{c}{ Equipment } \\
\hline Class I & Laser profilers: Non-contact lightweight \\
Precision profilers & profiling devices and portable laser profilers \\
& Manually operated devices: e.g. TRL \\
& beam, Face Dipstick/ ROMDAS Z-250, \\
& ARRB Walking Profiler
\end{tabular}

Class II

Other profilometer methods

\section{Class III}

IRI estimates from equations

Class IV

Subjective measures
APL profilometer, profile graphs (e.g. California, Reinhart), optical profilers, and inertial profilers (GMR)

Roadmaster, ROMDAS, Roughometer, TRL correlation Bump Integrator, rolling straightedge

Keycode rating systems, visual inspection, ratings/uncalibrated ride over the section

Source: Data Collection Technologies for Road Management [6]

The Hawkeye device which uses laser profilers is included in the Class I category, while the Roughometer is in Class III. Al-Rousan, Ibrahim and Amin [9] on their roughness measurement comparison study proved that the difference between the results of the precise manual roughness survey method and Roughometer III survey method is less than $0.19 \mathrm{~m} / \mathrm{km}$, which is less than the specified limits by the World Bank for Class 3 roughness measurement devices. Regarding that, the study proved that the Roughometer III is performed well as a roughness measure device. 


\subsection{Student's t-Test}

Descriptive statistical analysis with paired sample Student's t-test showed a graph that resembled normal standard distribution. If $n$ is close to infinity, the t-distribution will be the same as the normal distribution. The statistic formula of the Student's t-test used was as follows:

$$
\begin{gathered}
t=\frac{\left(\overline{x_{i}}-\overline{y_{i}}\right)}{\sqrt{\frac{S_{1}^{2}}{n 1}+\frac{S_{2}^{2}}{n 2}}-2 r * \frac{S_{1}}{\sqrt{n 1}} * \frac{S_{2}}{\sqrt{n 2}}} \\
S \approx \sqrt{\frac{\sum\left(x_{i}-\overline{x_{i}}\right)^{2}}{n-1}}
\end{gathered}
$$

Where:

$\mathrm{t}=\mathrm{t}$-value or $\mathrm{t}-\mathrm{score}$

$\overline{x_{i}}, \overline{y_{i}}=$ Mean of the IRI values from the Roughometer measurements with IRI values from the Hawkeye measurements.

$S \quad=$ Variance of IRI values from the Roughometer measurements with IRI values from the Hawkeye measurements.

$\mathrm{n} \quad=$ Number of observations

The student's t-test was aimed to prove the research hypotheses determined based on the research objectives. Decision-making was done based on:

- Criteria of the $t-v a l u e$, in which Ho was accepted if $t_{\text {count }}<t_{\text {tablea } / 2}$, but Ho was rejected if $\mathrm{t}_{\text {count }}>\mathrm{t}_{\text {table } \alpha / 2 \text {. }}$

- Probability (p-value), in which Ho was accepted if the probability $>0.05$. In contrast, Ho was rejected if the probability $<0.05[11]$.

\section{Research Methodology}

The research methodology of the study can be seen in the flow chart of Figure 3. 


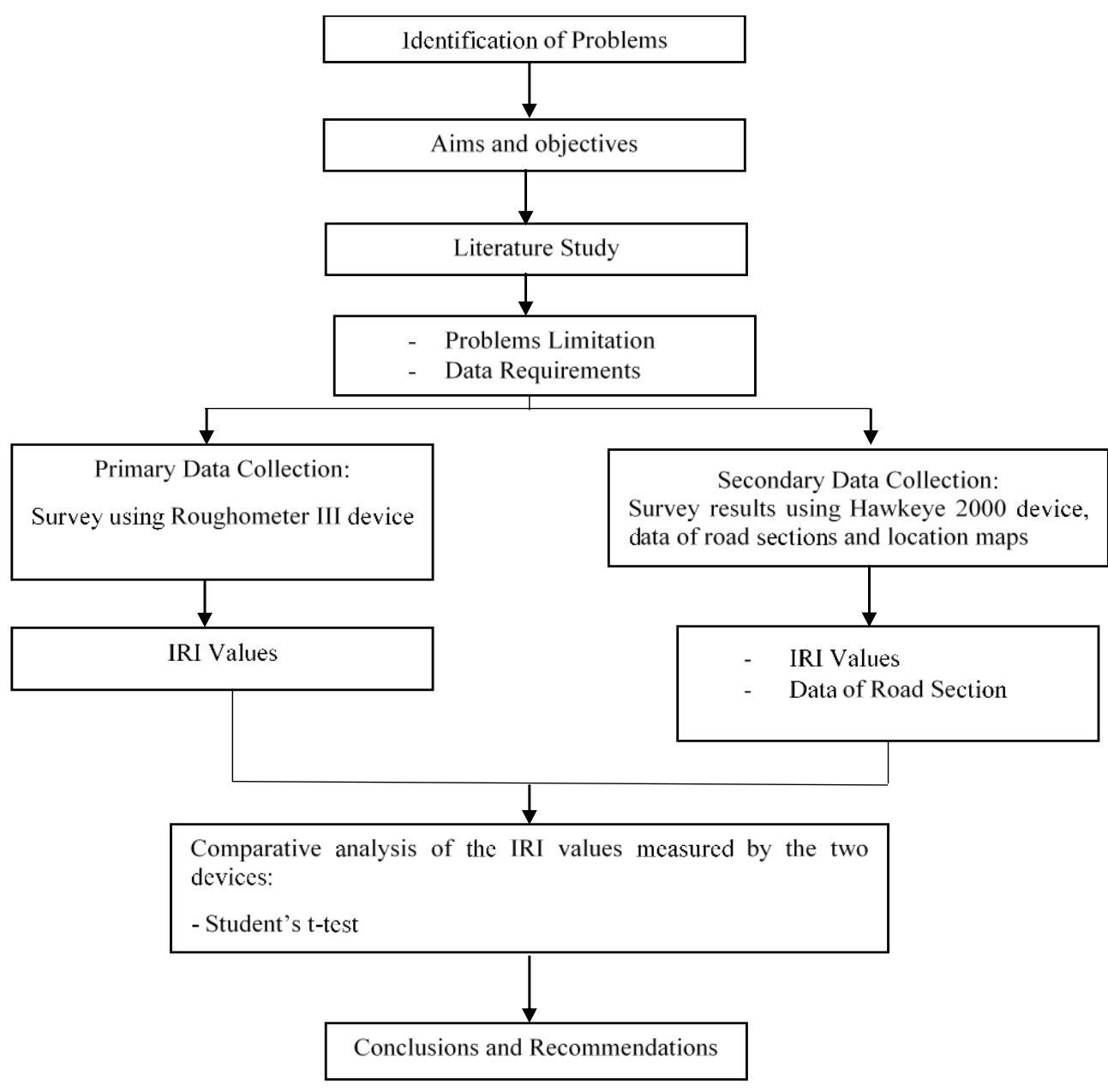

Figure 3 Flow Chart of Research Methodology

\section{Data Presentation}

The IRI data analyzed was data obtained from the measurements of Roughometer III and Hawkeye 2000 devices. The IRI values measured for the three road sections can be seen in Figure 4, Figure 5, Figure 6, Figure 7, Figure 8 and Figure 9. The IRI values analyzed statistically with Student's t-test were the IRI values for each 100 meters observation consisting of 2 directions-4 lanes and 2 directions- 2 lanes, and the IRI values were represented by the largest IRI value. The selection of the largest IRI value because the value can represent the worst condition of the road functions surveyed, so the worst condition that exists will be handled with a more appropriate type of maintenance[12]. 


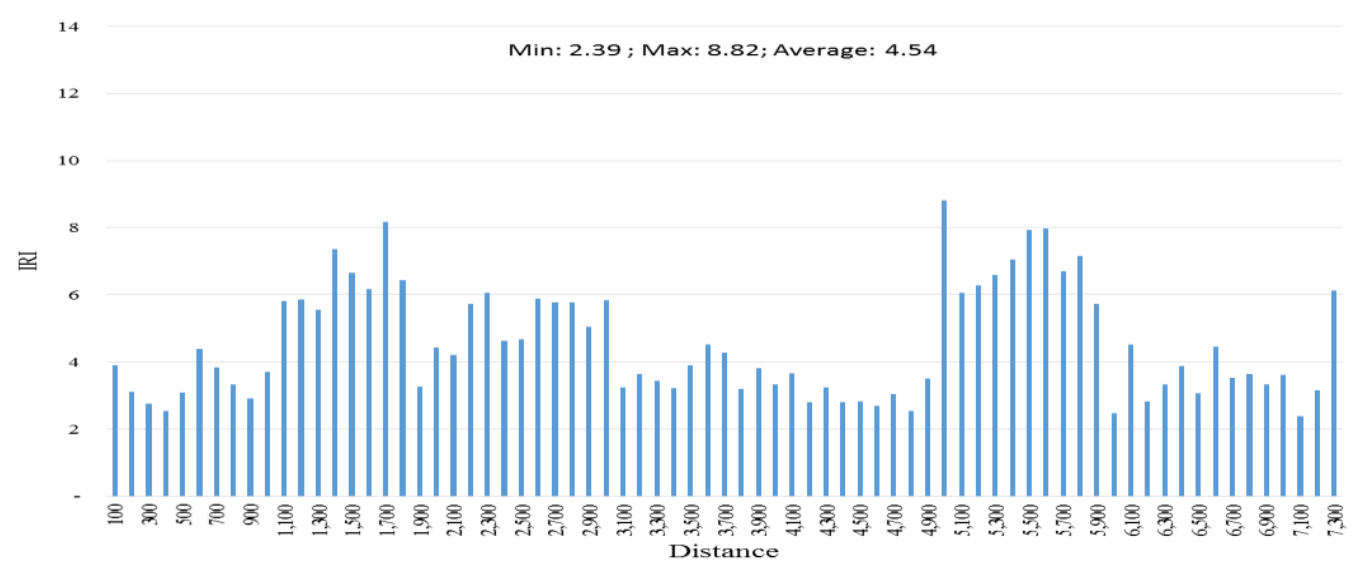

Figure 4. Graph of IRI values from Hawkeye in Bts. Binjai-Bts. Medan

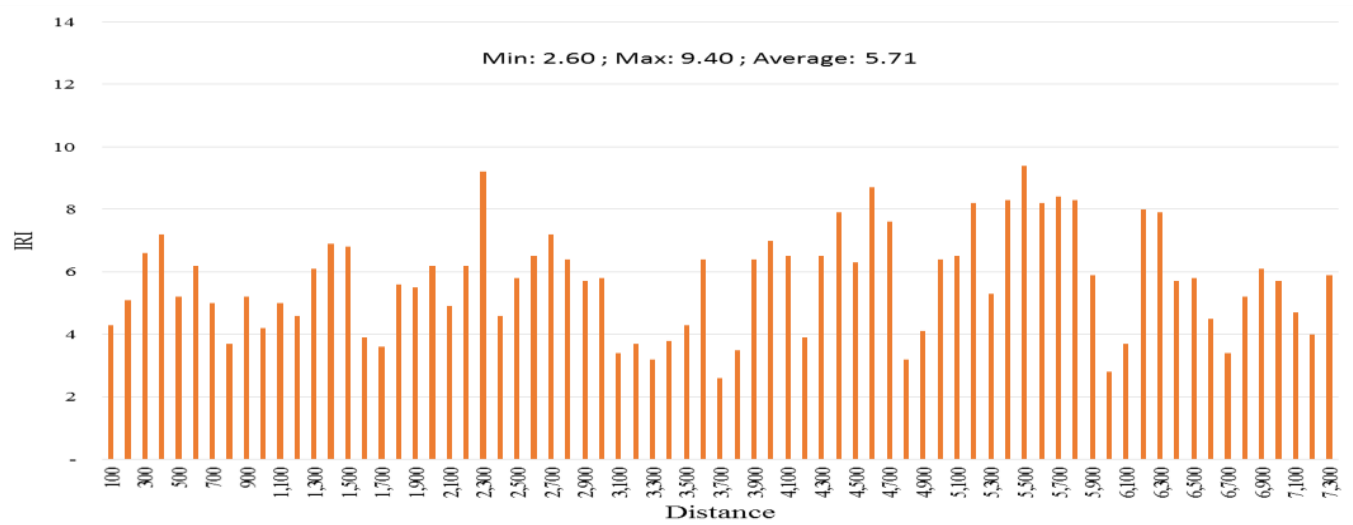

Figure 5. Graph of IRI values from Roughometer in Bts. Binjai-Bts. Medan

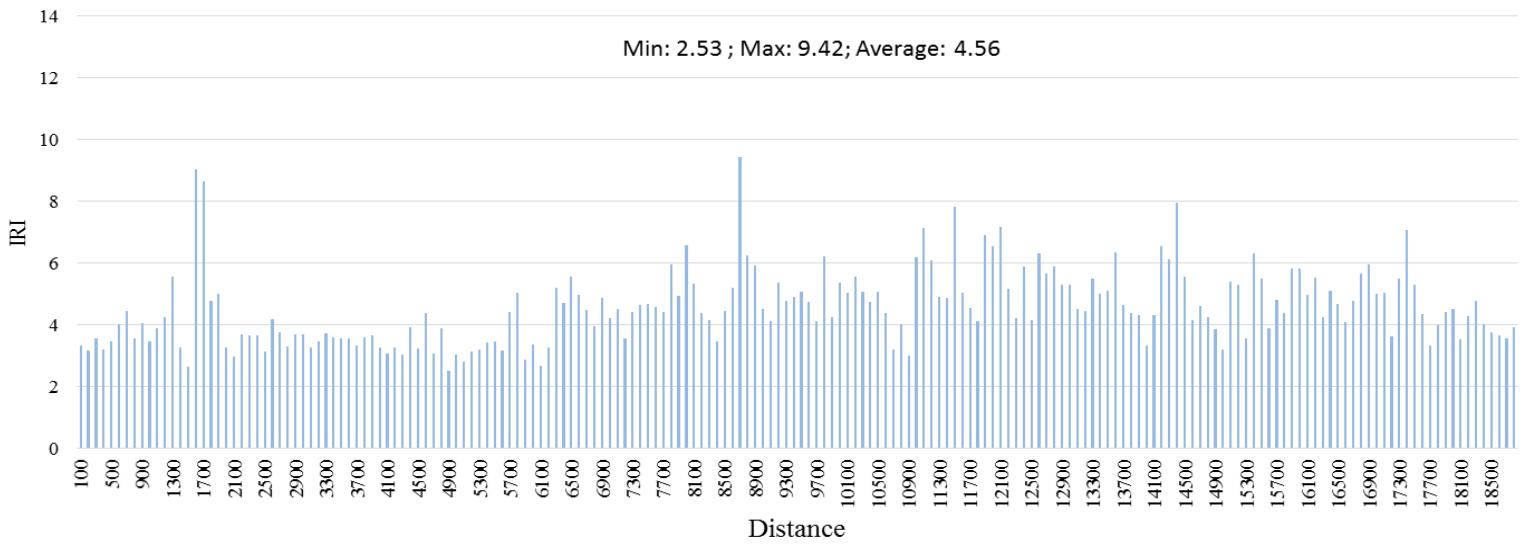

Figure 6. Graph of IRI values from Hawkeye in Bts. Tebing Tinggi-Bts. Simalungun 


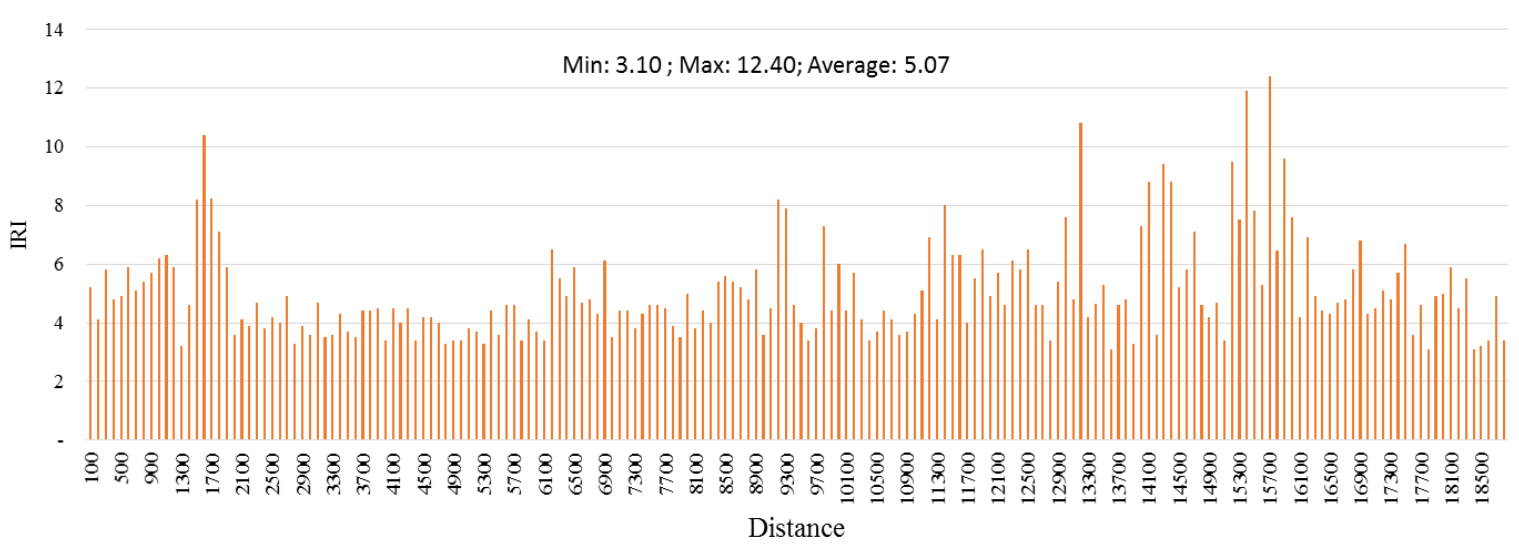

Figure 7. Graph of IRI values from Roughometer in Bts. Tebing Tinggi - Bts. Simalungun

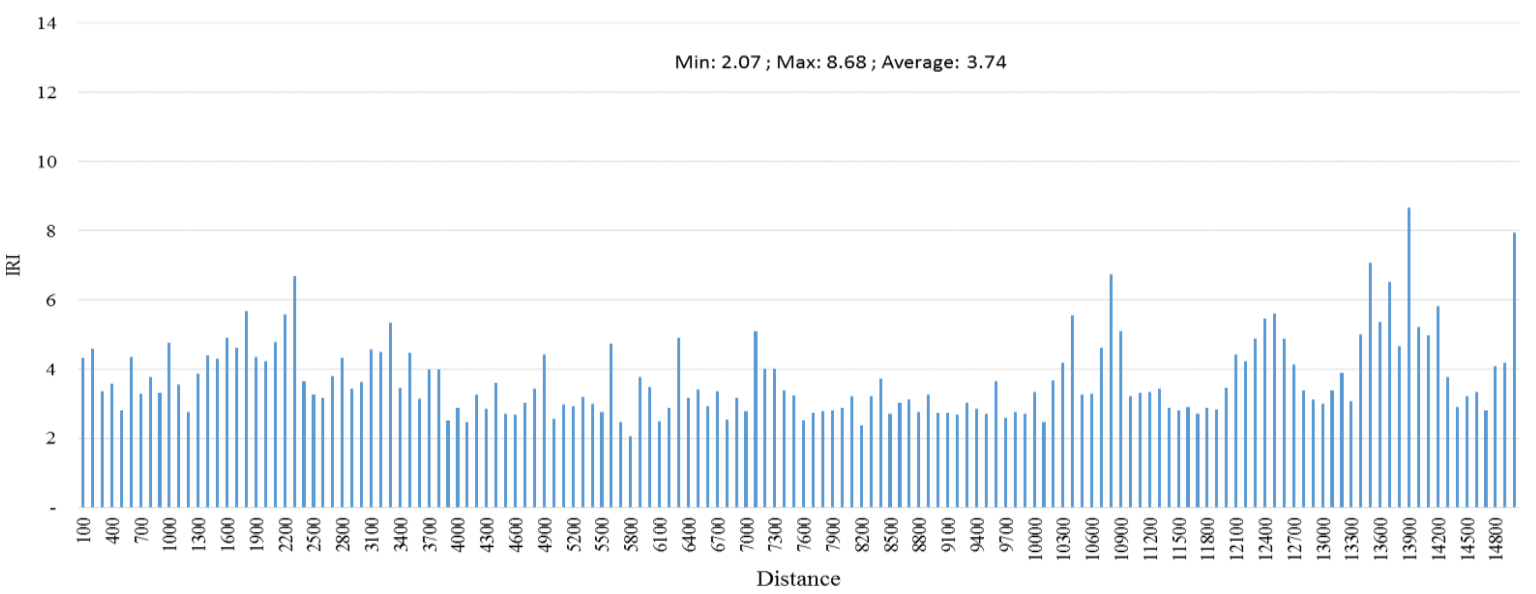

Figure 8. Graph of IRI values from Hawkeye in Bts. Simalungun / Sergai-Bts. Pematang Siantar

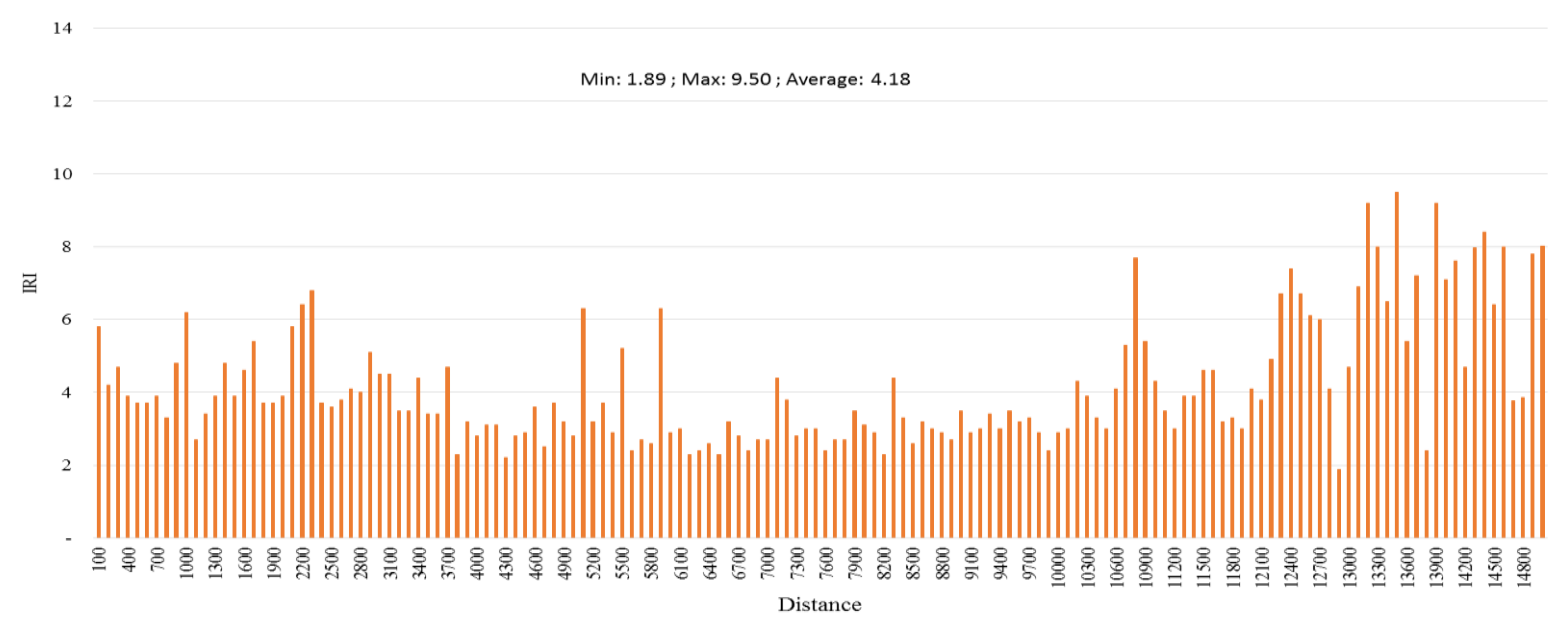

Figure 9. Graph of IRI values from Roughometer in Bts. Simalungun / Sergai-Bts. Pematang Siantar

\section{Comparative Analysis of the IRI Values}

Based on the statistic results of paired samples Student's t-test on the three road sections studied [13], Ho was rejected which means that the mean of IRI values from the Roughometer and 
Hawkeye measurements were significantly different in terms of the assessment of the road functional conditions as seen in Table 3.

Table 3. Results of Student's t-test of IRI

\begin{tabular}{|c|c|c|c|c|c|c|}
\hline \multirow{2}{*}{ Road Sections } & \multicolumn{4}{|c|}{ Student's t Test Results } & \multicolumn{2}{|c|}{ Means } \\
\hline & t-Statistic & $\mathrm{t}$-Critical & P Value & Probability & Roughometer & Hawkeye \\
\hline - Bts. Kota Binjai - Bts. Kota Medan & -5.331 & 1.994 & 0.000001104 & 0.05 & 5.725 & 4.546 \\
\hline $\begin{array}{l}\text { - Bts. Kota Tebing Tinggi-Bts. Kab. } \\
\text { Simalungun }\end{array}$ & -4.168 & 1.973 & 0.000047052 & 0.05 & 5.066 & 4.566 \\
\hline $\begin{array}{l}\text { - Bts. Kab. Simalungun/Kab. Sergei- } \\
\text { Bts. Kota P. Siantar }\end{array}$ & -3.887 & 1.976 & 0.000152833 & 0.05 & 4.166 & 3.732 \\
\hline
\end{tabular}

According to Table 3. statistically the IRI values measured by Roughometer were significantly different from the IRI values measured by Hawkeye (Ho was rejected) because the Student's ttest results for the three road sections showed that $t_{\text {count }}>t_{\text {critical }}$ and $p$-value $<0.05$ [14]. The measured result also shows the mean of IRI values measured by the Roughometer was greater than the mean of IRI values measured by Hawkeye [15]. The greater IRI number means the worst of road condition (table 1).

\section{Conclusions and Recommendations}

\subsection{Conclusions}

Based on the calculation results and data analysis about the hypothesis and research objectives, it can be concluded that:

- Statistically, the IRI values from Roughometer were significantly different from the IRI values from Hawkeye.

- The mean of IRI values measured by the Roughometer was greater than the mean of IRI values measured by Hawkeye. Therefore, the IRI values from Roughometer were more conservative in representing the functional conditions of the road if it was used as the substitute of IRI values from Hawkeye.

- In the road condition assessment, the IRI values were more conservative will show the road condition (Table 2. ) as it real or worse, thus using rough meter to determine the road maintenance program will result from appropriate maintenance or heavily maintenance.

\subsection{Recommendations}

Based on the research results and conclusions, the authors convey some recommendations to policymakers in managing road infrastructure and for further research, as follows:

- Although the IRI values produced by the Roughometer device can be used as an alternative to the Hawkeye device which is a more expensive device with the possibility 
of over design, the use of Hawkeye can manage road maintenance costs more efficiently.

The use of Hawkeye, therefore, is more recommended in the assessment of road functional conditions in addition to its wider use function.

- The results of the functional conditions survey can be considered in conducting a detailed structural analysis and establishing a maintenance program. A survey should be carried out on the structural conditions of the road to obtain a more appropriate type of maintenance and to prevent over design.

- The measurement should be done at the same time to ensure the similarity of the road conditions at the time of measurement. Measurement with both devices can be done sequentially with distance settings so that measurements for a section can be completed on the same day.

\section{References}

[1] Hermawan, Suprapto, M., Setyawan A., 2017. The Use of International Roughness Index and Structural Number for Rehabilitation and Maintenance Policy of Local Highway. Magister Maintenance and Rehabilitation Infrastructure Sebelas Maret University, Jl. Ir. Sutami 36 A Solo 57126, Indonesia.

[2] Bennett, C.R., Chamorro, A., Chen, C., Solminihac, H.d., Flintsch, G.W., 2007. Data Collection Technologies for Road Management. The World Bank East Asia Pacific Transport Unit, Washington DC.

[3] Directorate General of Highways the Ministry of Public Works. 2011. Indonesia Integrated Road Management System (IIRMS), Panduan Survai Kondisi Jalan Nomor SMD-03/RCS. Jakarta.

[4] Sanjaya, Y.A., Rosalina dan Syarwan, 2017, Evaluasi Tingkat Kerusakan Permukaan Jalan Untuk Menentukan Jenis Penanganan Dengan Sistem Penilaian Menurut Bina Marga (Studi Kasus Jalan Nasional Bireuen-Bts. Kota Lhokseumawe, Kecamatan Krueng Geukueh mulai Sta 253+000 s/d Sta 257+000), Vo. 1 e-jurnal.pnl.ac.id.

[5] Directorate General of Highways the Ministry of Public Works. 2011 b. Pedoman Konstruksi dan Bangunan Nomor 00104/P/BM/2011, Survei Kondisi Jalan. Jakarta.

[6] Directorate General of Highways the Ministry of Public Works. 2005. Pedoman Konstruksi dan Bangunan Nomor Pd T-05-2005-B, Perencanaan Tebal Lapis Tambah Perkerasan Lentur Dengan Metode Lendutan. Jakarta.

[7] Sayers, M.W., Karamihas, S.M., 1998. The Litle Book Of Profiling, Basic Information About Measuring and Interpreting Road Profiles, University of Michigan, America.

[8] Roberts, J.D. dan Martin, T.C., 1999. Recommendations for Monitoring Pavement Performance, ARRB, Australia.

[9] Al-Rousan, T., Asi I. dan Baker, A.A., 2010. Roughness Evaluation of Jordan Highway Network. Department of Civil Engineering, Hashemite University, P.O. Box 150459, Zarqa 13115, Jordan.

[10] Sudjana, Prof., Dr., MSc., 1992, Metoda Statistika, Edisi ke.5, Bandung.

[11] Suherman, 2008, Studi Persamaan Korelasi antara Ketidakrataan Permukaan Jalan dengan Indeks Kondisi Jalan, Jurnal Teknik Sipil Volume 8 No. 3 (206 -214).

[12] The Australian Road Research Board (ARRB), 2014. User Manual Hawkeye 2000 System. 500 Burwood Highway, Vermont South Victoria 3133, Australia 
[13] Surbakti, M., Doan, A., 2018. Priority of Road Maintenance Management Based on Halda Reading Range on NAASRA Method, IOP Conf. Series: Materials Science and Engineering 309012114.

[14] Hardiyatmo, H.C., 2007. Pemeliharaan Jalan Raya, Universitas Gajah Mada, Yogyakarta.

[15] M. Y. M. Putra, "Evaluasi Kondisi Fungsional dan Struktural Menggunakan Metode Bina Marga dan AASHTO 1993 Sebagai Dasar dalam Penanganan Perkerasan Lentur Studi Kasus : Ruas Medan - Lubuk Pakam,”vol. 20, no. 3, pp. 245-254, 2013. 